\title{
JADIKANLAH MURID: TUGAS PEMURIDAN GEREJA MENURUT MATIUS 28:18-20
}

\author{
I Putu Ayub Darmawan \\ Sekolah Tinggi Teologi Simpson \\ Jl. Agung No. 66, Krajan, Kel. Sususukan, Kec. Ungaran Timur, Kab. Semarang, Jawa Tengah \\ Email: putuayub.simpson@gmail.com
}

\begin{abstract}
I Putu Ayub Darmawan. Make Disciples: The Duty of Church Discipleship According to Matthew 28: 18-20. This article discusses the task of church discipleship according to Matthew 28: 1820. The author conducted a literature study to understand the intent of Matthew 28: 18-20 and to carry out the construction of the task of discipleship in the church. The task of discipleship, Jesus addressed his disciples, then proceeded to their successors who lived in a community of faith to carry out the task of discipleship. In the task of discipleship, the community of faith in a church as an institution takes action to proclaim the good news so that every nation can be part of a community of faith in Jesus Christ. In discipleship, everyone who enters the community of faith in Christ is accepted without distinction, because this task is a multicultural task. Teaching is an important part of the discipleship task. Teaching is done in order to strengthen new believers or new students enter the community of faith in Jesus, then they become disciples of the Lord Jesus who can be sent to disciple others.
\end{abstract}

Keywords: Discipleship, Church, Teaching, Community

Abstrak: I Putu Ayub Darmawan. Jadikanlah Murid: Tugas Pemuridan Gereja Menurut Matius 28:1820. Artikel ini membahas tentang tugas pemuridan gereja menurut Matius 28:18-20. Penulis melakukan studi pustaka untuk memahami maksud Matius 28:18-20 dan melakukan konstruksi tugas pemuridan gereja. Tugas pemuridan, Yesus tujukan kepada para murid-murid-Nya, kemudian dilanjutkan oleh pada penerus mereka yang hidup dalam sebuah komunitas iman untuk menjalankan tugas pemuridan tersebut. Dalam tugas pemuridan, komunitas iman dalam sebuah gereja sebagai suatu institusi melakukan tindakan pergi untuk mewartakan kabar baik sehingga setiap bangsa dapat menjadi bagian dari komunitas iman pada Yesus Kristus. Dalam pemuridan, setiap orang yang masuk dalam komunitas iman pada Kristus, diterima dengan tanpa membedakan mereka, sebab tugas ini adalah tugas yang multikultural. Pengajaran merupakan bagian penting dalam tugas pemuridan. Pengajaran dilakukan agar dapat memantapkan orang-orang yang baru percaya atau murid-murid baru masuk ke dalam komunitas iman pada Yesus, kemudian mereka menjadi murid Tuhan Yesus yang dapat diutus untuk memuridkan orang lain.

Kata kunci: Pemuridan, Gereja, Pengajaran, Komunitas

\section{PENDAHULUAN}

Masing-masing Injil memberi penekanan tentang murid. Injil Matius merupakan Injil yang memberikan perhatian lebih terhadap relasi Yesus dengan para murid. Hakh (2008, p. 95) menjelaskan bahwa istilah murid muncul sekitar empat puluh kali tanpa kesajajaran dengan dengan Markus dan Lukas. Penjelasan Hakh menunjukkan bahwa ada penekanan khusus Matius pada relasi Yesus dengan Murid dibandingkan dengan dua Injil lainnya. Selain itu, bagian akhir dari Injil Matius memberikan penekanan khusus pada para murid terkait tugas pemuridan.
Perhatian Matius pada hubungan Yesus dengan para murid tampaknya begitu menonjol, sehingga penekanan tersebut tampak dalam sebagaian besar Injil Matius. Pada bagian akhir Injil Matius, dituliskan suatu pernyataan yang Yesus Kristus ungkapkan kepada para murid dan pernyataan tersebut disebut pula sebagai amanat agung. Dalam Matius 28:18-20 dituliskan demikian

... Kepada-Ku telah diberikan segala kuasa di sorga dan di bumi. Karena itu pergilah, jadikanlah semua bangsa murid-Ku dan baptislah mereka dalam nama Bapa dan Anak dan Roh Kudus, dan ajarlah mereka melakukan segala 
sesuatu yang telah Kuperintahkan kepadamu. Dan ketahuilah, Aku menyertai kamu senantiasa sampai kepada akhir zaman.

Matius 28:18-20 pada umumnya disebut sebagai amanat agung dan cenderung dipahami sebagai amanat agung penginjilan. Wijaya (2012, p. 6) mengungkapkan bahwa pada masa kini mayoritas orang Kristen memahami inti dari Matius 28:18-20 adalah pada tugas penginjilan atau tugas misi. Faktor penyebabnya adalah perhatian cenderung tertuju pada kata "pergilah" yang diletakkan di awal kalimat. Serupa dengan penjelasan Wijaya, dalam tafsirannya Pasaribu (2005, p. 334) lebih menyoroti teks Matius 28:18-20 sebagai amanat agung untuk misi. Berhitu (2014, p. 274) mengungkapkan bahwa amanat agung dalam Matius 28:19-20 menekankan pada adanya tugas untuk memberitakan Injil dan membawa jiwajiwa kepada Tuhan.Demikian pula tafsiran Nixon (2007, p. 122) menjelaskan bahwa teks Matius 28: 18-20 memberi penekanan pada pemberitaan Injil, sementara pengajaran merupakan salah satu tugas saja. Memang tidak dapat dipungkiri bahwa dalam amanat tersebut ada tugas misi untuk mewartakan penyelamatan manusia, tetapi secara keseluruhan amanat tersebut merupakan tugas pemuridan.

Teks Matius 28:18-20 tidak berhenti pada kata pergilah yang cenderung dipahami sebagai tugas memberitakan Injil, melainkan terdapat pesan lanjutan yang juga sama pentingnya dengan bagian permulaan ayat tersebut. Silitonga (2018, p. 72-73) dalam jurnalnya menjelaskan bahwa salah satu sisi amanat agung adalah penginjilan "bertobatlah, sebab Kerajaan Allah sudah dekat" dan sisi kedua dari amanat agung tersebut adalah pemuridan. Amanat tersebut tidak berarti bahwa tugas gereja hanya melakukan sebuah sebuah program pelayanan serta gerakan penginjilan, melainkan tugas pemuridan bagi segala suku bangsa. Penjelasan Banawiratma (2006, p. 6) mengungkapkan bahwa amanat tersebut tidak hanya dipahami sebagai tugas pengutusan untuk bermisi melainkan amanat untuk melaksanakan pemuridan. Nainggolan (2014, p. 16) dalam kajiannya terhadap Matius 28:18-20 mengungkapkan bahwa teks tersebut merupakan fondasi tidak hanya untuk penginjilan, melainkan sebuah tugas pemuridan. Dari beberapa penjelasan di atas, jelas jika teks Matius 28:18-20 tidak hanya merupakan amanat misi atau penginjilan melainkan sebuah amanat untuk pemuridan yang diberikan kepada para murid untuk selanjutnya diteruskan kepada generasi penerusnya. Hartono (2018, p. 160) mengungkapkan bahwa inti dari amanat agung adalah kegiatan pemuridan, yang berimplikasi pada tugas penginjilan dan pengajaran untuk memperlengkapi setiap murid untuk melakukan pelayanan.

Silitonga (2018, p. 73) menjelaskan bahwa implementasi amanat agung dalam Matius 28:18-20, dalam konteks masa kini harus digarap oleh gereja secara institusional dan sistematis sehingga gereja dapat hadir di suatu tempat untuk membangun iman dan akhirnya memuji Tuhan. Gereja yang dimaksud dalam hal ini adalah sekolompok orang percaya atau komunitas iman Kristen yang diidentifikasi sebagai jemaat lokal (Darmawan, 2014, p. 206). Amanat agung tersebut perlu diimplementasikan sebagai tugas pemuridan. Nainupu (2017, p. 91) menjelaskan bahwa pemuridan merupakan bagian yang tak terpisahkan dari keseluruhan pelayanan gereja oleh sebab itu pemuridan harus dilakukan sebagai suatu usaha sadar yang dilakukan oleh dan dari gereja secara terencana dan secara sistematis dengan tujuan agar setiap orang percaya atau anggota gereja dapat memiliki iman yang berakar kuat di dalam Kristus. Demikian pula dikemukakan oleh Lie (2013, p. 17) bahwa Yesus telah menunjukkan bahwa gereja merupakan konteks pemuridan, di mana setiap orang dapat belajar dan bertumbuh. Dengan demikian Matius 28:18-20 harus dimaknai sebagai sebuah amanat agung yang tidak hanya untuk tugas penginjilan saja melainkan pula ada tugas pemuridan. Karena teks tersebut harus dipahami juga sebagai tugas pemuridan maka perlu dilakukan konstruksi tugas pemuridan gereja menurut Injil Matius 28:18-20.

Penulis memandang perlu melakukan rekonstruksi, karena konsep pemuridan cenderung hanya difokuskan pada pemuridan Paulus kepada Timotius, 
padahal teks ini merupakan awal dari adanya kegiatan pemuridan dalam komunitas Kristen mulamula. Beberapa buku pemuridan lebih menonjolkan pemuridan yang dilakukan oleh Paulus terhadap Timotius dan hanya menyinggung Matius 28:18-20 sebagai dasar bahwa pemuridan merupakan amanat agung Kristus. Oleh sebab itu, karena Matius 28:1820 merupakan teks Perjanjian Baru yang memberi penekanan awal tentang pemuridan maka konstruksi tugas pemuridan gereja harus dimulai dari teks ini.

Rumusan masalahnya adalah bagaimana tugas pemuridan gereja menurut Injil Matius 28:1820? Adapun tujuan penulisan ini adalah untuk memaparkan tugas pemuridan gereja menurut Injil Matius 28:18-20.

\section{METODE}

Pendekatan yang digunakan dalam penelitian ini adalah pendekatan studi pustaka. Untuk dapat memaparkan tentang tugas pemuridan gereja, penulis melakukan pembacaan terhadap Injil Matius 28:18-20, kemudian melakukan analisis terhadap teks tersebut. Untuk membantu proses analisis, penulis melakukan studi pustaka terhadap berbagai sumber pustaka berupa jurnal teologi maupun buku, sehingga diperoleh gambaran tentang tugas pemuridan gereja menurut Matius 28:18-20. Dalam proses penelitian ini, penulis menggunakan juga pengetahuan yang penulis peroleh dari literatur, diskusi akademik, forum ilmiah dan pengetahuan yang dibentuk dari pengalaman melalui interaksi kehidupan bergereja. Pengetahuan tersebut kemudian dikembangkan dengan melakukan pembacaan terhadap berbagai sumber literatur yang membahas maupun menyinggung teks yang Matius 28:19-20.

Tahap pertama yang penulis lakukan adalah melakukan pembagian terhadap teks Matius 28:1920, kemudian memahami kata-kata dalam teks tersebut, lalu hasil dari pemahaman tersebut dipaparkan secara deskriptif sistematis sesuai dengan pengetahuan yang diperoleh dari literatur, diskusi akademik, forum ilmiah (knowledge by description) dan pengetahuan yang dibentuk dari pengalaman melalui interaksi kehidupan bergereja (knowledge by experience). Analisis terhadap teks Matius 28:18-20 tidak sepenuhnya dilakukan dengan proses analisis kata, melainkan dilakukan diskusi antara analisis awal dengan berbagai pengetahuan yang telah diperoleh. Bagian akhir paparan setiap topik, disertai dengan implikasi untuk menjadikan hasil paparan dapat diimplikasikan pada masa kini.

\section{HASIL DAN PEMBAHASAN}

\section{Penerima Amanat Agung}

Dalam cerita Matius 28:16-20, tugas pemuridan Yesus tujukan kepada para murid-murid-Nya. Henry (2008, p. 1567-1570) menjelaskan bahwa tugas tersebut diberikan kepada orang-orang yang diutus-Nya, terutama para murid yang merupakan pelayan utama dalam Kerajaan Kristus. Tugas tersebut kemudian diteruskan kepada para penerus mereka yang menjadi pelayan Injil Kristus. Jika diperhatikan teks Matius 28:16-20 maka jelas jika Yesus memberikan tugas pemuridan kepada kesebelas murid pada sebuah bukit di Galilea. Berdasarkan teks Matius 28:16, "Dan kesebelas murid itu berangkat ke Galilea, ke bukit yang telah ditunjukkan Yesus kepada mereka," jelas jika tugas pemuridan diberikan kepada kesebelas murid. Tugas tersebut kemudian dilanjutkan oleh pada penerus mereka yang hidup dalam sebuah komunitas iman untuk menjalankan tugas pemuridan tersebut (Kis. 2:14-47). Komunitas tersebut bertekun dalam pemberitaan Injil sebagai wujud dari pergi untuk menjadi semua suku bangsa murid Kristus, kemudian bertekun dalam pengajaran para rasul. Komunitas iman tersebut kemudian dikenal sebagai gereja. Penerus para rasul melakukan tugas pemuridan karena dalam teks Matius 28:20 diberi penekanan agar mengajarkan para penerus mereka untuk melakukan apa yang telah diperintahkan oleh Yesus, termasuk dalam hal ini tugas pemuridan. Dengan demikian jelas bahwa teks Matius 28:18-20 juga merupakan tugas pemuridan gereja masa kini. Sebab gereja masa kini merupakan generasi penerus dari pelayanan yang telah 
diteruskan oleh para rasul kepada penerusnya, kemudian diteruskan kembali kepada para murid, demikian seterusnya hingga gereja masa kini. Gereja pada masa kini juga merupakan komunitas iman yang harus melaksanakan perintah Yesus, termasuk tugas pemuridan.

Bagi gereja pada masa kini, sebagai sebuah institusi maupun setiap orang sebagai komunitas iman merupakan penerima amanat tersebut. Itu sebabnya, tugas pemuridan merupakan tugas gereja pada masa kini. Jika tugas pemuridan merupakan tugas gereja masa kini maka proses pemuridan menjadi perhatian penting dalam setiap pelayanan gereja.

\section{Memaknai Pergilah dalam Tugas Pemuridan}

Dalam teks Matius 28:19, Yesus memerintahkan agar para murid pergi menjadikan segala bangsa ( $\varepsilon \theta v o \varsigma$ - ethnos) sebagai murid Yesus ("Indo Greek, Leksikon Yunani” Sabda). Kata pergi dalam teks tersebut menurut Henry (2008, pp. 1570-1571) berarti bahwa para rasul maupun penerusnya harus pergi kepada semua orang untuk memberitakan keselamatan dan keselamatan itu adalah keselamatan yang terbuka buat semua orang. Sementara Nubantimo (2013, p. 300) menjelaskan bahwa kata pergilah dalam teks Matius 28:19 dapat dimaknai sebagai pergi seperti yang Yesus lakukan, di mana Ia pergi dalam kesediaan untuk menunjukkan kasih yang tidak memihak, melakukan penyangkalan diri, pengharapan, kematian dan kebangkitan Kristus. Sesuai dengan teks Matius 28:19 maka jelas jika dalam tugas pemuridan, pertama-tama yang harus dilakukan adalah "Pergilah, jadikanlah semua bangsa muridKu." Kata pergilah dalam ayat tersebut dapat dimaknai sebagai tugas untuk mewartakan kabar baik sehingga setiap bangsa dapat menjadi bagian dari komunitas iman pada Yesus Kristus. Pergi menjadikan segala bangsa murid Kristus adalah tugas untuk menjadikan semua bangsa sebagai bagian dari komunitas pemuridan, menjadi bagian dari komunitas iman pada Kristus. Tugas pergi adalah tugas kemuridan, yang menurut Sin $(2017$, p. 43$)$ disebut sebagai proses menjadikan seseorang sebagai murid.
Pendapat senada dikemukakan oleh Hakh (2008, pp. 96-97) yang menjelaskan bahwa tugas menjadikan murid merupakan suatu proses untuk membawa orang lain masuk ke dalam persekutuan yakni gereja. Untuk membawa orang lain masuk dalam komunitas iman, setiap orang Kristen harus melakukan tindakan pergi kepada semua suku bangsa. Servant (2004, p. 9) juga menjelaskan bahwa teks dalam Matius 28:19 Yesus menghendaki jika pemuridan harus dilakukan kepada semua bangsa atau semua kelompok etnis di dunia. Oleh sebab itu, dalam tugas pemuridan gereja perlu tindakan pergi untuk mewartakan kabar baik dengan berbagai cara sehingga setiap orang dapat masuk dalam komunitas iman. Maka dalam melaksakanan tugas pemuridan gereja, pertama-tama yang harus dilakukan adalah menjadikan orang lain menjadi anggota komunitas tersebut.

Teladan dalam tugas ini adalah Yesus sendiri. Sebelum Ia memberikan amanat ini, Yesus telah terlebih dahulu melakukan tugas pergi. Pertamatama Ia pergi dari Surga ke dunia untuk menyelamatkan manusia, kemudian dalam pelayanan-Nya di bumi Ia pergi berkeliling dari satu tempat ke tempat yang lain untuk mewartakan kabar baik (Mat. 9:3538). Nainupu (2017, p. 135) menjelaskan bahwa sebelum Yesus memberikan amanat, Ia telah terlebih dahulu melakukan tugas pemuridan tersebut. Ia telah membangun suatu komunitas murid dengan memilih dua belas orang murid, sebagai persiapan generasi penerus dari semangat pemuridan. Demikian pula dituliskan oleh Darmawan bahwa dalam memulai pemuridan, Yesus terlebih dahulu memanggil beberapa orang untuk masuk dalam komunitasnya, kemudian Ia memilih beberapa murid untuk Ia muridkan secara khusus (Darmawan, 2017, p. 35). Untuk memilih kedua belas murid, Yesus membangun satu relasi yang baik dengan orang-orang yang dipilihNya, Ia menghampiri para calon murid dan mengundang mereka masuk dalam komunitas-Nya. Oleh sebab itu, pemurid perlu membangun relasi yang baik dengan semua orang, sebab pemuridan merupakan relasi baik itu formal maupun informal untuk menolong satu sama lain untuk mengikut Yesus 
(Oei, 2017, p. 71). Dengan adanya relasi yang baik maka tugas menjadikan semua orang dapat dilaksanakan dengan baik. Seorang pemurid melakukan tugas ini tidak untuk mewartakan sesuatu yang menakutkan melainkan mewartakan shalom bagi banyak orang, itu sebabnya relasi yang baik dengan banyak orang berperan penting dalam tugas ini.

Implikasi bagian ini bagi gereja pada masa kini adalah gereja sebagai institusi maupun sebagai komunitas iman tidak hanya fokus pada kegiatan di dalam melainkan melakukan tugas pewartaan kabar baik untuk membawa shalom dan akhirnya setiap orang yang dilayani dapat menjadi bagian dari komunitas. Program-program gereja perlu disusun untuk mendukung tugas pergi menjadikan segala bangsa menjadi murid.

\section{Pemuridan yang Multikultural}

Dalam teks Matius 28:19, Yesus memerintahkan agar menjadikan segala bangsa ( $\varepsilon \theta v o \varsigma$ ethnos) sebagai murid-Nya ("Indo Greek, Leksikon Yunani" Sabda). Segala bangsa dalam teks tersebut menunjukkan bahwa amanat tersebut harus diselenggarakan pada semua suku bangsa (multikultural). Pelaksanaan tugas ini tidak hanya ditujukan pada satu kelompok suku, melainkan berbagai suku bangsa. Oleh sebab itu, tugas pemuridan dilakukan pada semua suku bangsa, dan itu artinya tugas pemuridan dilakukan dengan pendekatan yang multikultural. Pendekatan multikultural yang dilakukan dengan landasan berpikir humanis menurut Lie (2013, p. 9) dapat menimbulkan bahaya dalam penyelenggaraan pemuridan. Pendekatan multikultural dalam konteks kekristenan adalah pendekatan yang memperhatikan sisi antroplogi dari sudut pandang Alkitab. Dari sudut pandang Alkitab, manusia adalah ciptaan yang diciptakan segambar dengan rupa Allah, jatuh dalam dosa, dan setiap orang yang percaya kepada Yesus Kristus diselamatkan. Dengan demikian pendekatan multikultural akan memperhatikan adanya potensi kreatif manusia sebagai ciptaan yang segambar dengan gambar Allah, tetapi kreatifitas manusia juga dapat berupa kreatifitas yang jahat karena adanya dosa, dan dapat dipulihkan oleh karena karya Kristus.

Silitonga (2018, p. 75) mengungkapkan bahwa gereja memiliki tugas untuk menjelaskan kepada setiap anggota komunitas dari berbagai suku bangsa bahwa Allah adalah pencipta dan pemeliharan seluruh ciptaan termasuk manusia. Selain itu, kepada setiap suku bangsa harus dijelaskan bahwa Allah adalah penebus manusia dari dosa. Karena tugas pemuridan merupakan tugas yang harus dilakukan kepada segala suku bangsa, maka dalam implementasinya pemuridan memperhatikan keberagaman etnis yang ada dalam komunitas iman. Perbedaan suku bangsa dalam sebuah komunitas iman diterima sebagai bagian dari komunitas dan menjadi mitra bersama dalam bertumbuh dan melaksanakan amanat agung.

\section{Penerimaan dalam Komunitas Pemuridan}

Terkait dengan multikultural dan pemuridan ada sebuah upaya menerima setiap orang sebagai bagian dari komunitas pemuridan. Dalam tugas pemuridan, terdapat perintah untuk melakukan baptisan "Baptislah mereka." Melalui baptisan, seseorang menyatakan komitmennya untuk mengikut Kristus, kemudian masuk dalam komunitas orang percaya. Henry (2008, pp. 1573-1574) menjelaskan bahwa baptisan dilakukan dalam nama Bapa dan Anak dan Roh Kudus, itu berarti baptisan dilakukan dengan kuasa dari Surga. Selain itu, dengan baptisan dalam nama Bapa dan Anak dan Roh Kudus, berarti bahwa setiap orang yang masuk sebagai bagian dalam komunitas iman pada Yesus mempercayai Bapa, Anak dan Roh Kudus. Karena tugas pemuridan dilakukan pada semua bangsa, maka tugas ini merupakan tugas yang multikultural. Itu sebabnya setiap orang yang masuk dalam komunitas iman pada Kristus, diterima dengan tanpa membedakan mereka. Setiap orang percaya lainnya dalam komunitas tersebut harus menerima orang tersebut tanpa memandang warna kulit, suku, kasta, strata sosial dan lain sebagainya. Sebab semua orang yang masuk dalam komunitas orang percaya memiliki status 
yang sama yaitu murid yang harus belajar firman Allah, bertumbuh, dan akhirnya berbuah.

Dalam konteks masa kini, persoalan yang timbul di beberapa gereja adalah adanya gap atau kesenjangan antar satu kelompok dengan kelompok lain maupun satu golongan dengan golongan lainnya. Selain itu, permasalahan yang terjadi adalah penerimaan terhadap setiap orang yang masuk dalam komunitas iman. Bila diimplementasikan secara baik maka komunitas iman menjadi komunitas yang terbuka bagi semua orang, sebab Yesus memerintahkan agar pergi kepada semua bangsa. Itu berarti bahwa komunitas iman pada Yesus harus terbuka bagi semua orang.

\section{Pengajaran dalam Proses Pemuridan}

Dalam teks Matius 28:20, tugas pemuridan dilaksanakan dengan melakukan pengajaran (kata Yunani). Diana (2018, p. 28) menjelaskan bahwa Matius 28:19-20 berbicara tugas "ajarlah" agar setiap anggota komintas iman dapat melakukan apa yang Kristus ajarkan. Lie (2013, pp. 17-18) mengungkapkan bahwa Yesus melakukan pola pemuridan yang menekankan adanya pengajaran, yang kemudian diikuti oleh para murid dan para pemimpin jemaat mula-mula yang mengajar jemaat untuk taat pada pengajaran-Nya. Pola yang para rasul dan pemimpin jemaat lakukan adalah pola yang selaras dengan amanat agung Yesus dalam Matius 28:19-20.

Agar setiap orang percaya dalam komunitas mengalami pertumbuhan maka dalam komunitas tersebut, pengajaran harus dilakukan. Selain itu, setiap murid yang telah dibaptis harus memperhatikan dan melaksanakan segala sesuatu yang telah diperintahkan Kristus. Oleh sebab itu, setiap murid harus menerima pengajaran firman Tuhan. Keterlibatan mereka dalam sebuah gereja sebagai komunitas iman adalah untuk mencapai sesuatu yang lebih dalam yaitu memperhatikan dan melaksanakan perintah Kristus. Dalam amanat tersebut, Yesus Kristus meminta agar melakukan tugas pengajaran, "Ajarlah" $(\delta i \delta \alpha \sigma \kappa \omega-$ didasko). Ia ingin agar para rasul dan penerusnya termasuk gereja pada masa kini ini, menanamkan pengajaran dan ketetapan-ketetapan Allah kepada para murid lainnya. Hakh (2008, p. 96) menjelaskan bahwa dalam konteks Matius 28:18-20, murid-murid diutus untuk tugas mengajar, bukan tugas menyembuhkan orang, mengusir setan, membuat mujizat dan membangkinkan orang mati. Tugas tersebut diberikan karena murid-muridmerupakan kelompok yang aktif dalam mengajar, sama sepertiyang Yesus lakukan.

Komunitas tersebut menjadi komunitas belajar yang mendorong terjadinya pertumbuhan iman dan pengenalan akan Kristus. Selan (2014, p. 83) mengungkapkan bahwa amanat agung pemuridan dengan melakukan pengajaran bukan merupakan sebuah pilihan, melainkan suatu amanat yang harus ditaati. Pengajaran bukan merupakan pekerjaan sampingan, melainkan salah satu pelayanan pokok gereja dan tidak hanya ditujukan pada kelompok tertentu melainkan kepada semua kelompok. Pengajaran memegang peranan penting dalam keseluruhan program pelayanan dalam jemaat untuk mewujudkan kedewasaan para murid (Selan, 2014, p. 83).

\section{Pelaksana Tugas Pengajaran}

Bila melihat teks Matius 28:16, tugas pemuridan ditujukan kepada kesebelas murid. Kesebelas murid tersebut dapat dikategorikan sebagai murid yang telah dewasa. Murid-murid tersebut kemudian diberi mandat untuk melakukan tugas pemuridan, dimana pengajaran merupakan tugas mereka. Para murid tersebut harus menjadikan setiap orang sebagai murid Yesus, lalu diajar agar menjadi taat dan melakukan perintah-Nya.

Mencermati teks tersebut, maka setiap orang dalam komunitas iman pada Yesus yang telah dewasa secara rohani dengan dibuktikan adanya sikap taat pada Allah serta melakukan perintah-Nya, bertanggungjawab untuk mengajar murid baru. Demikian seterusnya, setiap murid yang telah dewasa melakukan tugas pengajaran. Darmawan (2017, p. 43) menjelaskan jika teks dalam Matius 28:19-20 menunjukkan bahwa Yesus menginginkan agar para murid terus bertumbuh kemudian memuridkan lebih 
banyak orang untuk melakukan Rencana Agung Allah. Gambaran tugas tersebut dilakukan sebagaimana ilustrasi berikut ini:

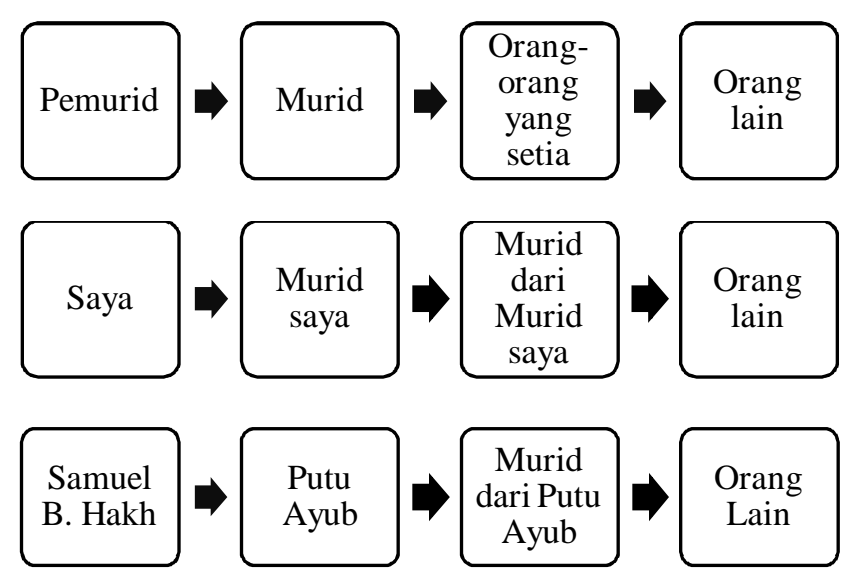

Gambar 1. Konsep Pelaksana Pemuridan, Mengacu pada Faisal (2014, p. 180).

Dari gambar tersebut jelas jika setiap orang yang telah menjadi murid, kemudian menerima pengajaran dan menjadi dewasa melakukan tugas pengajaran ini sebagai bagian dari tugas pemuridan. Bagi gereja pada masa kini, setiap orang yang menjadi bagian dari komunitas iman bertanggungjawab untuk mengajar murid baru sehingga mereka menjadi orang Kristen yang taat dan melakukan perintah-perintah-Nya.

\section{Tujuan Pengajaran}

Penulis mencermati jika tugas pengajaran dalam Matius 28:20 dilaksanakan dengan tujuan antara lain:

\section{Menjadi Orang Kristen Taat}

Teks "ajarlah mereka melakukan segala sesuatu yang telah Kuperintahkan kepadamu" dalam Matius 28:20 dapat dimaknai bahwa pengajaran bertujuan agar setiap orang dalam komunitas menjadi orang Kristen yang taat pada ketetapan Allah. Silitonga (2018, p. 73) menjelaskan bahwa pengajaran dalam pemuridan berfungsi untuk memantapkan orang-orang yang baru percaya atau muridmurid baru masuk ke dalam komunitas iman pada Yesus. Kemudian Servant (2004, p. 67) menjelaskan bahwa dalam pemuridan, murid-murid diajar untuk menaati semua perintah Yesus.
Henry (2008, pp. 1575-1577) menjelaskan bahwa tugas pengajaran gereja adalah menyampaikan perintah-perintah Kristus, dan menjelaskannya kepada para murid, dan menekankan pentingnya ketaatan terhadap perintah-perintah itu serta membantu mereka menerapkan perintah-perintah Kristus dalam perkara-perkara tertentu. Mereka tidak boleh mengajarkan ketentuan-ketentuan mereka sendiri kepada murid-murid, melainkan mengajarkan ketetapan-ketetapan Allah yang harus senantiasa ditaati. Orang-orang Kristen harus dilatih untuk mengetahui ketetapan-ketetapan-Nya itu. Karena itu, suatu pelayanan tetap harus dibentuk di dalam gereja, untuk membangun tubuh Kristus, sampai setiap orang dalam komunitas iman pada Kristus telah mencapai kedewasaan penuh (Ef. 4:11-13). Setiap orang dalam komunitas tersebut harus selalu ada di dalam pengawasan para pengajar dan pemimpin sampai mereka dewasa. (Henry, 2008, pp. 1575-1577). Dalam konteks gereja, Sin (2017, p. 47) menjelaskan pula bahwa dalam pemuridan terdapat tugas pengajaran agar setiap orang dalam komunitas mempunyai kehidupan yang taat kepada Allah atau memiliki kedewasaan secara rohani dalam Kristus serta dapat "menularkan" ketaatannya itu kepada orang lain. Sin menekankan pentingnya ada pengajaran sebagai implementasi dari Matius 28:20, karena sama seperti yang Yesus lakukan ketika memuridkan para murid, pemuridan merupakan proses seorang murid menjadi seperti gurunya.

Situasi yang sedikit berbeda terjadi pada masa kini, di mana gereja sebagai komunitas orang percaya cenderung abai dengan tugas pengajaran. Ada kalanya pengajaran berhenti pada khotbahkhotbah hari minggu dengan komunikasi satu arah. Padalah sebagai komunitas iman, gereja dapat menjadi tempat belajar, menggali bersama firman Tuhan. Bila mencermati nats dalam Kisah Para Rasul 2:4147, tampak jika orang percaya mula-mula hidup dalam pengajaran dan persekutuan dengan interaksi satu dengan yang lain. Sebagai murid Kristus, kita harus mempelajari dan mengenali kewajiban kita menurut hukum Kristus, karena itu gereja juga men- 
jadi komunitas belajar di mana setiap orang diizinkan masuk dan belajar di sana.

\section{Pengajaran Untuk Menjadi Pemurid}

Pengajaran dilakukan sebagai usaha agar para murid dapat melakukan tugas pemuridan. Teks "ajarlah mereka melakukan segala sesuatu yang telah Kuperintahkan kepadamu" dalam Matius 28:20 dapat dimaknai bahwa setiap murid juga harus melakukan tugas pemuridan sebab tugas pemuridan merupakan perintah dari Yesus. Nainupu (2017, p. 106) menjelaskan bahwa setelah para murid mengikuti Yesus kemudian menjadi murid Tuhan Yesus barulah kemudian mereka diutus untuk memuridkan orang lain. Penjelasan Nainupu menunjukkan jika setelah menjadi murid dan memperoleh pengajaran, setiap orang diutus untuk melakukan pemuridan. Oleh sebab itu, pengajaran harus diberikan agar setiap orang dalam komunitas memiliki kemampuan dan keterampilan untuk melakukan pemuridan. Kemudian Silitonga (2018, p. 73) menjelaskan bahwa gereja mengembangkan proses pemuridan dengan tujuan agar setiap orang dalam komunitas ditolong, diarahkan dan diajar untuk dapat melakukan tugas pemberitaan Injil sebagai bagian dari proses pemuridan. Karena setiap orang dalam komunitas iman harus melakukan tugas pemuridan maka pengajaran dilakukan untuk memperlengkapi mereka sehingga mereka melakukan tugas pemuridan. Simanjuntak (2014, p. 252) menjelaskan bahwa dalam tugas pemuridan sesuai dengan Matius 28:19-20, pengajaran diberikan sebagau usaha memperlengkapi mereka yang percaya menjadi murid Tuhan. Darmawan (2017, p. 37) menjelaskan bahwa dalam melaksanakan tugas pemuridan, gereja memberi perhatian setiap anggota komunitas baru dengan memberikan pengajaran, kemudian dirawat serta dilatih dengan dasar-dasar kehidupan Kristen sehingga menjadi seorang murid yang terlatih. Oleh sebab itu, tugas pemuridan gereja harus mencapai tujuan agar setiap orang dalam komunitas terlatih untuk melakukan pemuridan dan menjadi pelaku pemuridan.
Morris (2016, p. 759) menjelaskan bahwa dalam Injil Matius, murid adalah pembelajar dan sekaligus pengikut. Murid-murid-Nya melihat Yesus sebagai sosok Guru dan belajar dari-Nya, tetapi mereka juga mengikutinya. Itu artinya para murid telah belajar dari pada-Nya bagaimana melayani (Mat. 28:20). Dalam memberikan amanat tersebut, Yesus telah lebih dahulu mengajar para murid bagaimana melayani. Bila memperhatikan teks Matius 9:35-38 berikut,

Demikianlah Yesus berkeliling ke semua kota dan desa; Ia mengajar dalam rumah-rumah ibadat dan memberitakan Injil Kerajaan Sorga serta melenyapkan segala penyakit dan kelemahan. Melihat orang banyak itu, tergeraklah hati Yesus oleh belas kasihan kepada mereka, karena mereka lelah dan terlantar seperti domba yang tidak bergembala. Maka kata-Nya kepada murid-murid-Nya: "Tuaian memang banyak, tetapi pekerja sedikit. Karena itu mintalah kepada tuan yang empunya tuaian, supaya Ia mengirimkan pekerja-pekerja untuk tuaian itu."

Jelas jika Yesus telah terlebih dahulu mengajar para murid dengan menjadi model pembelajaran. Itu artinya sebelum mengutus para murid, Yesus telah terlebih dahulu mengajar para murid. Dengan demikian jelas bahwa proses pemuridan merupakan proses dimana pemurid memuridkan muridnya untuk menjadi pemurid.

Untuk menjadikan para murid sebagai pemurid yang terlatih, Yesus telah meluangkan seluruh waktu-Nya untuk memperlengkapi dan membuat murid-murid-Nya melayani. Yesus juga meluangkan waktu-Nya untuk melatih pada murid bagaimana melayani, selain itu Ia juga melakukan evaluasi terhadap pelaksanaan pelayanan para murid, motif mereka melaayani seperti yang terjadi dalam Matius 26:6-13 (Darmawan, 2017, pp. 37-38). Apa yang Yesus lakukan merupakan sebuah model bagi pelayanan pemuridan masa kini. Gereja perlu melatih para murid untuk menjadi pemurid yang terampil. Tanpa sebuah latihan, mereka akan menghadapi berbagai hambatan. 


\section{KESIMPULAN}

Tugas pemuridan gereja merupakan amanat agung dari Yesus Kristus. Tugas tersebut dilaksanakan dengan pertama-tama pergi kepada semua orang untuk menjadikan mereka sebagai bagian dari komunitas iman. Dalam cerita Matius 28:16-20, tugas pemuridan sebagaimana dituliskan dalam teks Matius 28:16-20, Yesus tujukan kepada para muridmurid-Nya, tugas tersebut kemudian dilanjutkan oleh pada penerus mereka yang hidup dalam sebuah komunitas iman untuk menjalankan tugas pemuridan tersebut (Kis. 2:14-47). Yesus memerintahkan agar para murid pergi menjadikan segala bangsa ( $\varepsilon \theta v o \varsigma$ ethnos), tidak terbatas kelompok maupun strata sosial tertentu menjadi sebagai murid Yesus. Kata pergi dalam teks tersebut berarti bahwa setiap orang yang telah menjadi murid bertanggungjawab untuk pergi kepada semua orang untuk memberitakan keselamatan yang terbuka buat semua orang. Yesus Kristus sendiri adalah teladan dalam melakukan tugas ini. Bagi gereja pada masa kini, baik secara institusional maupun sebagai komunitas iman bertanggungjawab melakukan tugas pewartaan kabar baik untuk membawa shalom bagi semua orang.

\section{DAFTAR RUJUKAN}

Alkitab (TB). Jakarta: Lembaga Alkitab Indonesia, 2008.

"Indo Greek, Leksikon Yunani" Sabda (OBL versi Indonesia) 5.10.00.3.

Banawiratma, J.B. 2006. "Misi Dan Dakwah: Berbagi Iman demi Kemaslahatan Umat Manusia," Gema Teologi, 30 (2): 1-13.

Berhitu, R.J. 2014. "Peran Gembala Jemaat Terhadap Pengembangan Pelayanan Holistik Di Gereja Kemah Injil Indonesia Jemaat Yegar Sahaduta Jayapura." Jurnal Jaffray, 12 (2): 273-290.

Darmawan, I P.A. 2017. "Murid yang Memuridkan," dalam Melaksanakan Amanat Agung di Abad 21, editor I Putu Ayub Darmawan. Ungaran: Sekolah Tinggi Teologi Simpson.
Dalam tugas tersebut, setiap orang yang masuk dalam komunitas iman dibaptis dalam nama Bapa, Anak, dan Roh Kudus sebagai bentuk menyatakan komitmennya untuk mengikut Kristus. Karena tugas pemuridan dilakukan pada semua bangsa, maka tugas ini merupakan tugas yang multikultural, sehingga setiap orang yang masuk dalam komunitas iman Kristen diterima dengan tanpa membedakan warna kulit, suku, kasta, maupun strata sosial.

Dalam tugas pemuridan gereja, terdapat tugas pengajaran. Setiap orang yang telah menjadi murid dan dewasa secara rohani, melakukan tugas pengajaran sehingga setiap orang yang masuk dalam komunitas iman menjadi orang Kristen taat. Hal itu sesuai dengan teks "ajarlah mereka melakukan segala sesuatu yang telah Kuperintahkan kepadamu" (Mat. 28:20). Kemudian setiap orang yang telah masuk dalam komunitas iman Kristen diajar agar memiliki kemauan, kemampuan, dan keterampilan menjadi pemurid. Untuk melaksanakan tugas tersebut, pemurid perlu meluangkan waktunya, sebagaimana yang Yesus lakukan untuk memperlengkapi dan membuat para murid melakukan tugas pemuridan.

Darmawan, I.P.A. 2014. "Peran Gereja Dalam Pendidikan Nasional."Jurnal Simpson: Jurnal Teologi dan Pendidikan Agama Kristen, I (2): 205-216.

Diana, R. 2018. "Permasalahan Pembinaan Warga Jemaat di Kewari." Evangelikal: Jurnal Teologi Injili dan Pembinaan Warga Jemaat, 2 (1): 28-35.

Faisal (Penerjemah). 2014. Pemuridan Yang Dinamis: Pribadi ke Pribadi. Bandung: Kalam Hidup.

Hakh, S.B. 2008. Pemberitaan Tentang Yesus Menurut Injil-Injil Sinoptik. Bandung: Jurnal Info Media.

Hartono, H. 2018. "Mengaktualisasikan Amanat Agung Matius 28:19-20 dalam Konteks Era 
Digital." KURIOS (Jurnal Teologi dan Pendidikan Agama Kristen), 4 (2): 157-166.

Henry, M. 2008. Tafsiran Matthew Henry: Injil Matius 15-28, penerjemah Herdian Apriliani, dkk. Surabaya: Momentum dan Oikonomos Foundation.

Lie, T.G. 2013. "Tantangan Dalam Pendidikan Dan Pengajaran Masa Kini," Jurnal Stulos, 12 (1): 1-24.

Morris, L. 2016. Injil Matius. Surabaya: Momentum. Nainggolan, B.D. 2014. "Konsep Amanat Agung Berdasarkan Matius 28:18-20 Dalam Misi." Jurnal Koinonia, 8 (2): 15-45.

Nainupu, M. 2017. "Pemuridan Melalui Pendekatan Konseling Pastoral," Jurnal Theologia Aletheia, 19 (12): 91-140.

Nixon, R.E. \& Nasution, H.P. (penerj.). 2007. "Matius" dalam Tafsiran Alkitab Masa Kini 3: Matius - Wahyu. Jakarta: Yayasan Komunikasi Bina Kasih.

Nubantimo, E.I. 2013. "Pencarian Kesaksian Kristen Yang Relevan di Asia (Kosuke Koyama: Injil Menurut Pandangan Asia)," Jurnal Ledalero, 12 (2): 289-309.

Oei, A.W. 2017. "Khotbah Yang Kontekstual: Memuridkan Para Pengkhotbah Untuk
Memuridkan Jemaat," Jurnal Theologia Aletheia, 19 (12): 69-90.

Pasaribu, M. 2005. Eksposisi Injil Sinoptik: Mengenal Yesus yang Diberitakan dalam Injil Matius, Markus dan Lukas. Malang: Gandum Mas.

Selan, R.F. 2014. "Dikotomi: Jurusan PAK dan Jurusan Teologi (Berpisah atau Bermitra?)," Jurnal Simpson: Jurnal Teologi dan Pendidikan Agama Kristen, 1 (1): 81-94.

Servant, D.A. 2004.Pelayanan Pemuridan: PrinsipPrinsip Alkitabiah untuk Berbuah dan Bertumbuh. n.p.: Ethnos Press.

Silitonga, R. 2018. "Amanat Agung Dan Kemajemukan Agama: Suatu Refleksi," Jurnal Stulos, 16(1): 69-89.

Simanjuntak, J.M. 2014. "Implikasi Konsep dan Desain Kurikulum Dalam Tugas Pembinaan Warga Jemaat," Jurnal Jaffray, 12 (2): 251271.

Sin, S.K. 2017. "Adakah Metode Pemuridan Dalam Perjanjian Lama?," Jurnal Theologia Aletheia, 19 (12): 43-68.

Wijaya, H. 2012. "Misi dan Pelayanan Sosial." Makalah Strategi Misi, Sekolah Tinggi Theologia Jaffray, Makassar. 